Joanna Kubaszczyk ${ }^{1}$

Uniwersytet im. Adama Mickiewicza w Poznaniu

Wydział Neofilologii

\title{
„Drzwi zamknięte” czy „otwarte bramy”, czyli tłumacz między profanum a sacrum
}

W wyborze esejów Sacrum, mit, historia Mircea Eliade stwierdza, że człowiek religijny „sytuuje się zarazem w środku świata i u samego źródła rzeczywistości absolutnej, tuż przy «otworze», który umożliwia mu porozumiewanie się z bogami”². W podobnej sytuacji znajduje się thumacz literatury religijnej i teologicznej, oscylując w swej pracy między profanum a sacrum. Z jednej strony grozi mu bowiem, że na skutek jego decyzji ów „otwór” zostanie zamknięty, czyli dojdzie do desakralizacji tekstu, który nie będzie już pozwalał na „porozumiewanie się” z Bogiem, z drugiej zaś strony rozstrzygnięcia tłumacza prowadzić mogą do nadmiernej sakralizacji tekstu tam, gdzie autor religijny sytuuje się świadomie „w środku świata”.

Ale metafora „drzwi zamkniętych” i „otwartych bram” odnosi się również do innych aspektów tego rodzaju przekładu. Co sprawia, że teksty religijne i teologiczne mogą być hermetyczne dla thumacza, który zwykle porusza się w sferze profanum? Czy czasami również są hermetyczne dla thumacza obytego ze sferą sacrum? Na jakie trudności napotyka, które mogą spowodować, że tekst docelowy staje się hermetyczny dla odbiorcy? Jaka jest specyfika przekładu tekstów o tematyce religijnej bądź teologicznej? Czym przekład tekstów religijnych i teologicznych różni się od przekładu innych tekstów, jeżeli w ogóle się różni? To tylko niektóre pytania, które można w tym kontekście zadać i podjąć próbę znalezienia na nie odpowiedzi.

\section{Rola słowa w chrześcijańskich tekstach religijnych}

Przekonanie, że teksty religijne różnią się i powinny się różnić od tekstów ze sfery profanum towarzyszy ludzkości od początku. W czasach przedchrześcijańskich podział na to, co święte, i to, co świeckie, był bardzo klarowny, wyraźny,

${ }^{1}$ Dr hab. Joanna Kubaszczyk, prof. UAM - germanistka, przekładoznawczyni, thumaczka literatury teologicznej (gluck@amu.edu.pl).

2 M. Eliade, Sacrum, mit, historia, Warszawa 1993, s. 88. 
często związany ze sferą tabu. Dziś nie jest on już jednak czymś oczywistym³; dla chrześcijanina sacrum i profanum się przenika. Wynika to z tego, że - jak zauważa Eliade - „dla judaizmu, ale przede wszystkim dla chrześcijaństwa bóstwo objawiło się w historii”" Dlatego chrześcijanin, nie mogąc ani odrzucić historii, ani przyjąć jej w całości, „[m]usi nieustannie wybierać, dążyć do odróżnienia w masie wydarzeń historycznych — tego wydarzenia, które dla nie go może mieć znaczenie odkupicielskie"s. Takim wydarzeniem może być słowo z przypisywaną mu przez judaizm i chrześcijaństwo wielką mocą sprawczą:

Zaiste, podobnie jak ulewa i śnieg spadają z nieba i tam nie powracają, dopóki nie nawodnią ziemi, nie użyźnią jej i nie zapewnią urodzaju, tak iż wydaje nasienie dla siewcy i chleb dla jedzącego, tak słowo, które wychodzi z ust moich, nie wraca do Mnie bezowocne, zanim wpierw nie dokona tego, co chciałem, i nie spełni pomyślnie swego posłannictwa (Iz 55,10-11 ${ }^{6}$.

Słowo może być rozumiane zatem w tekstach religijnych nie tylko jako słowo ludzkie, ale przede wszystkim jako słowo Boże. Słowo to ma moc stwórczą i zbawczą. W liście św. Jakuba Apostoła czytamy: „Przyjmijcie w duchu łagodności zaszczepione w was słowo, które ma moc zbawić dusze wasze” (Jk 1,21), a więc słowo ma moc uzdrawiającą, może być ratunkiem, powodem przemiany. Szczególną moc słowom przypisuje się oczywiście nie tylko w chrześcijaństwie, ale i w innych religiach czy działaniach rytualnych. Ważne jest jednak, żeby podkreślić, że słowo w tekstach religijnych nie jest rzeczywistością obojętną. Jeżeli ma być słowem Bożym, to musi być dane. Wyraża to na przykład św. Paweł, pisząc do jednej z pierwszych gmin w Efezie:

Weźcie też hetm zbawienia i miecz Ducha, to jest słowo Boże — wśród wszelakiej modlitwy i błagania. Przy każdej sposobności módlcie się w Duchu! Nad tym właśnie czuwajcie z całą usilnością i proście za wszystkich świętych i za mnie, aby dane mi było słowo, gdy usta moje otworzę, dla jawnego i swobodnego głoszenia tajemnicy Ewangelii, dla której sprawuję poselstwo jako więzień, ażebym jawnie ją wypowiedzial, tak jak winienem (Ef 6,17-20).

Wiąże się z tym przekonanie, że niektóre teksty, szczególnie Pismo Święte, są natchnione, to znaczy ich autorstwo nie jest czysto ludzkie, ale udział w ich powstawaniu ma Duch Święty. Dobitnie wyraża to Benedykt XVI w adhortacji Verbum Domini ${ }^{7}$ :

3 Tamże, s. 194.

4 Tamże, s. 193.

5 Tamże, s. 193-194 (wszystkie wytłuszczenia w tekstach cytowanych pochodzą od autorki artykułu, natomiast wyróżnienie za pomocą druku rozstrzelonego zastosowano do miejsc podkreślonych przez autorów cytowanych prac).

6 Wszystkie cytaty biblijne za Biblia Tysiaclecia, wyd. 3 poprawione, Poznań-Warszawa 1980.

7 Adhortacja apostolska Verbum Domini, [online] https://w2.vatican.va/content/dam/benedict-xvi/pdf/apost_exhortations/documents/hf_ben-xvi_exh_20100930_verbum-domini_pl.pdf [11.12.2018]. 
Tak więc słowo Boże wyraża się ludzkimi słowami dzięki działaniu Ducha Świętego. Misja Syna oraz misja Ducha Świętego są nierozłączne i stanowią jedyną ekonomię zbawienia. Ten sam Duch, który działa we wcieleniu Słowa w łonie Dziewicy Maryi, kieruje także Jezusem podczas całej Jego misji i zostaje obiecany uczniom. Ten sam Duch, który mówił przez proroków, wspiera i inspiruje Kościół w dziele głoszenia słowa Bożego i w przepowiadaniu Apostołów; ostatecznie to ten sam Duch, który natchnął autorów świętych Pism (VD 15).

Słowo wiąże się również z aspektem przybliżania się do sacrum i wyrażania tajemnicy, na co wskazuje cytowany św. Paweł. Ponieważ słowo w tekstach religijnych dotyka rzeczywistości duchowej, więc szczególnie istotne jest otwarcie się na Ducha św., który przez słowo przemawia. Słowo okazuje się zatem w chrześcijaństwie owym „otworem”, umożliwiającym komunikację, porozumienie się z Bogiem, ale tylko wtedy, gdy ten, kto posługuje się słowem, otwiera się na działanie Ducha Bożego. Dotyczy to również tłumaczy, jeżeli słowo przełożone ma zachować moc. Tłumacz posługujący zatem na przykład podczas spotkań ewangelizacyjnych poza przygotowaniem merytorycznym powinien być otwarty na działanie Ducha św. W przekładzie religijnym następuje stąd podwójne otwarcie na Innego. Tłumacz otwiera się na tego, kto głosi, ale jednocześnie na Tego, którego głosi głoszący. Podobnie jak głoszący staje się narzędziem. Na ten aspekt bycia narzędziem wskazuje dobitnie ewangelicki teolog Dietrich Bonhoeffer:

Apostołowie są wybranymi przez Boga świadkami faktów objawienia w Jezusie Chrystusie. Żyli w cielesnej wspólnocie Jezusa, widzieli Tego, który stał się człowiekiem, ukrzyżowanego, zmartwychwstałego i dotykali rękoma Jego ciała (1 J 1:1). Są świadkami, których Bóg, Duch Święty, używa jako narzędzi do przekazania Słowa. Kazanie apostołów to świadectwo cielesnego wydarzenia, jakim było objawienie Boga w Jezusie Chrystusie. Na tym fundamencie apostołów i proroków zbudowany jest Kościół, którego kamień węgielny to Jezus Chrystus (Ef 2:20). Wszelkie późniejsze kazanie musi być również apostolskie i budować na tym fundamencie. Jedność między nami a pierwszą wspólnotą opiera się więc na słowie apostołów. W jakim stopniu nauka apostolska sprawia, że nieodzowne staje się nieustanne słuchanie? Słowo apostolskie jest w słowie ludzkim prawdziwym Słowem Bożym (1 Tes 2:13), które chce przyjąć ludzi i posiada taką moc. Słowo Boże szuka zboru, aby go przyjąć. Jest istotne w zborze, samo z siebie wchodzi do niego i ma własną, skierowaną ku zborowi dynamikę. Nie dzieje się tak, że z jednej strony jest słowo, jakaś prawda, a z drugiej zbór, kaznodzieja zaś tylko sięga po słowo, posługuje się nim, porusza nim, aby zanieść je do zboru i zastosować je do niego. Wręcz przeciwnie — Słowo pokonuje tę drogę samo z siebie, kaznodzieja nie powinien i nie może zrobić nic poza służbą dynamice Słowa, poza nieprzeszkadzaniem mu. Słowo wychodzi w świat, aby przyjąć ludzi; wiedzieli o tym apostołowie i to kształtowało ich kazanie ${ }^{8}$.

Bonhoeffer podkreśla w tym fragmencie podmiotowość Słowa, które przychodzi „samo z siebie”. Rolą kaznodziei oraz tłumacza — w rozważanej tutaj sytuacji podwójnego zapośredniczenia — jest nieprzeszkadzanie Słowu. Stąd tak istotna okazuje się moim zdaniem duchowa dyspozycyjność, znajdująca konkretny wyraz w tym, że dla tłumaczy pełniących posługę religijną nie tylko wa-

${ }^{8}$ D. Bonhoeffer, Naśladowanie, Katowice 2017, s. 206-207. 
runkiem sine qua non jest bycie osobą wierzącą, ale i w kontekście katolickim zwykle odpowiednie przygotowanie w formie odbycia spowiedzi.

Bonhoeffer porusza ponadto kwestię ,słuchania”. Słuchanie, a nawet więcej, nieustanne wsłuchiwanie się w żywe Słowo, by je potem móc przekazać, to kolejny aspekt pracy tłumacza chrześcijańskich tekstów religijnych. Słuchanie wiąże się etymologicznie z posłuchem i posłuszeństwem. Na ów aspekt posłuszeństwa wskazuje również cytowany teolog, zauważając, że „wiara i posłuszeństwo tworzą nierozerwalną całość" i warunkiem wiary"10. Aspekt posłuszeństwa jest szczególnie wart uwagi w czasach emancypacji thumacza i traktowania tekstu oryginału jako „oferty informacyjnej", jak czynią to np. zwolennicy teorii Skopos ${ }^{11}$. Taka - zautonomizowana - postawa tłumaczy wobec tekstu da się zaobserwować m.in. w niektórych współczesnych przekładach biblijnych jak w krytykowanym przekładzie niemieckim Bibel in gerechter Sprache ${ }^{12}$, w odniesieniu do którego zarzuca się zespołowi thumaczy i wydawcom ,zdradę Ewangelii"13 czy ,zafałszowanie” ${ }^{14}$ oraz że nie doczytali oni kończących Pismo św. wersów Apokalipsy (Ap 22,18-19) ostrzegających zarówno przed usunięciem, jak i dołożeniem czegokolwiek do tej księgi ${ }^{15}$. Wymaga to jednak od thumacza właśnie postawy posłuszeństwa i pokory, stanięcia w autorytecie i podporządkowania się mu. Kwestia samowolnych rozszerzeń (amplifikacji), eliminowania bądź innych nieuzasadnionych modyfikacji jest oczywiście kwestią etyczną w każdym rodzaju przekładu, w przekładzie religijnym nabiera jednak szczególnej wagi ${ }^{16}$. Chrześcijanie wierzą bowiem,

9 Tamże, s. 50.

10 Tamże, s. 51.

${ }^{11}$ K. Reiss, H.J. Vermeer, Towards a General Theory of Translational Action: Skopos Theory Explained, Manchester 2013, s. 33.

${ }_{12}$ Bibel in gerechter Sprache, hrsg. v. U. Bail, F. Crüsemann, M. Crüsemann, E. Domay, Gütersloh 2006. Dosłowny przekład tego tytułu brzmi Biblia w sprawiedliwym języku, jednak wysuwane są postulaty, by tłumaczyć go jako „Biblia w języku oddającym sprawiedliwość (kobietom)” (E. Adamiak, Imię Boga jest nieprzettumaczalne. Spór o przekłady Pisma Świętego, „Tygodnik Powszechny” 2.01.2007), por. też A. Gomola, Myśl feministyczna w przekładach Biblii, „Przekładaniec" 24/2011, s. 212-227, tu: s. 221.

${ }_{13}$ D. Gutzen, „Denn wer dolmetzschen wil, mus grosse vorrath von worten haben”. Von Luthers Bibelübersetzung zur Bibel in gerechter Sprache [w:] Gutes Übersetzen: Neue Perspektiven für Theorie und Praxis des Literaturübersetzens, hrsg. v. A. Buschmann, Berlin-Boston 2015, s. 243-281, tu: s. 281.

${ }^{14}$ R. Smend, Wohltuendes Durcheinander. Biblische Predigten, Stuttgart 2007, s. 10. Tu: za D. Gutzen, Denn wer dolmetzschen wil, s. 281.

15 D. Gutzen, Denn wer dolmetzschen wil, s. 281.

${ }^{16} \mathrm{~W}$ odniesieniu do tekstów religijnych można mutatis mutandis odnieść następujące zalecenie z Instrukcji Liturgiam authenticam: „należy przede wszystkim mieć na uwadze zasadę, że przekład tekstów liturgicznych liturgii rzymskiej ma być nie tyle dziełem artystycznym, ile raczej wiernym i dokładnym oddaniem w języku narodowym oryginalnych tekstów. Chociaż wolno korzystać ze swobody w doborze słów oraz stosować składnię i styl odpowiednie do tekstu w języku 
że wiara rodzi się ze słuchania. Stąd słowo musi być głoszone z mocą w posłuszeństwie, a wezwanie do służby Słowu jest rodzajem powołania, co dotyczy również tłumaczy. W tym miejscu pojawia się jednak pytanie o to, komu thumacz ma być w rozumieniu słowa posłuszny. Odpowiedź dla katolika jest jasna Kościołowi ${ }^{17}$. Ale również w Kościołach protestanckich posłuszeństwo zborowi w rozumieniu i głoszeniu słowa jest według Bonhoeffera rzeczą oczywistą, co wiąże się z rozpoznaniem herezji i wykluczeniem heretyka, brak jednak instancji nadrzędnej, którą w katolicyzmie jest Urząd Nauczycielski Kościoła, w związku z czym ocena różnych zborów może być odmienna:

Rozpoznanie granicy między dozwolonym poglądem jakiejś szkoły a herezją nie zawsze jest proste. Dlatego w niektórych zborach toleruje się pewne nauki jako pogląd danej szkoły, podczas gdy w innym usunięto je już jako herezje (Obj 2:6.15n). Gdy jednak herezja staje się oczywista, konieczne jest jej całkowite wykorzenienie. Głosiciel herezji zostaje wykluczony ze zboru chrześcijańskiego i z osobistej wspólnoty (Ga 1:8; 1 Kor 16:22; Tt 3:10; 2 J 10n). Słowo czystego zwiastowania musi widzialnie łączyć i dzielić. W ten sposób jasno ukazuje się przestrzeń zwiastowania i porządku zboru w ustanowionej przez Boga konieczności ${ }^{18}$.

\section{Tradycja}

W chrześcijaństwie słowo trzeba usłyszeć w wierze i w Tradycji, czyli w łączności z tymi, którzy je wcześniej usłyszeli:

Albowiem i myśmy otrzymali dobrą nowinę, jak i tamci, lecz tamtym słowo usłyszane nie było pomocne, gdyż nie łączyli się przez wiarę z tymi, którzy je usłyszeli (Hbr 4,2).

Odnosi się to również do pracy tłumacza tekstów chrześcijańskich, który nie może abstrahować od Tradycji i wspólnoty wierzących, czyli Kościoła, inaczej słowo nie będzie „pomocne”, a może być nawet „szkodliwe”. Zwykle kojarzy się takie podejście - i zapewne poniekąd słusznie — z katolicyzmem. Zasadę współdziałania Tradycji, Pisma św. i Urzędu Nauczycielskiego Kościoła przywołuje Konstytucja dogmatyczna o Objawieniu Bożym:

narodowym i do toku mowy, który jest właściwy dla języka ojczystego, to jednak wypada, aby tekst oryginalny, czyli pierwotny, na ile to możliwe, był tłumaczony bardzo wiernie i bardzo dokładnie, a mianowicie bez jakichkolwiek opuszczeń albo dodatków, co do jego treści, oraz bez wprowadzania parafraz i glos; przystosowanie tekstu do właściwości i przymiotów różnych języków narodowych powinno być nieznaczne i przeprowadzone ostrożnie" (pkt 20).

${ }^{17} \mathrm{~W}$ wypadku dzieł wydawanych drukiem wyrazem aprobaty Kościoła jest nihil obstat czy imprimatur; dopuszczanie do liturgii ksiąg liturgicznych, w tym lekcjonarzy i ewangeliarzy, leży w gestii konferencji biskupów (por. KPK, kan. 838 § 3); http://www.trybunal.mkw.pl/Kodeks\%20 Prawa\%20Kanonicznego.pdf [12.11.2018].

${ }^{18}$ D. Bonhoeffer, Naśladowanie, s. 209-210. 
Jasne więc jest, że święta Tradycja, Pismo Święte i Urząd Nauczycielski Kościoła, wedle najmądrzejszego postanowienia Bożego, tak ściśle się ze sobą łączą i zespalają, że jedno bez pozostałych nie może istnieć, a wszystkie te czynniki razem, każdy na swój sposób, pod natchnieniem jednego Ducha Świętego przyczyniają się skutecznie do zbawienia dusz ${ }^{19}$.

W katolicyzmie zakłada się za Drugim Listem św. Piotra, że „żadne proroctwo Pisma nie jest dla prywatnego wyjaśnienia”, bo w Piśmie zawarte są „trudne do zrozumienia pewne sprawy, które ludzie niedouczeni i mało utwierdzeni opacznie tłumaczą, [...], na własną swoją zgubę" (2 P 3,16). Innymi słowy, odczytanie tekstu Biblii wymaga merytorycznego przygotowania. Poprawnemu odczytaniu Biblii służy wielość metod. Papieska Komisja Biblijna w dokumencie Interpretacja Pisma Świętego w Kościele omawia stosowane metody, pragnąc „wskazać drogi do takiej interpretacji Pisma św., które ujawniałyby równocześnie ludzki i Boski charakter tej Księgi" ${ }^{20}$. Od tłumacza wymaga to odczytywania słowa w Tradycji, nie zaś dowolnie. Przejawia się to między innymi w tym, że przekładając teksty, w których cytowane jest Pismo św., tłumacz zasadniczo powinien korzystać z zaaprobowanych przez Kościół przekładów Biblii, a nie tłumaczyć na własną rękęę . Czasami może stać się to problemem, gdy istnieją rozbieżności w przekładach na poszczególne języki wynikające np. z wieloznaczności pojęć i autor nadbudowuje sens wywodów na konkretnym przekładzie, który nie ma swego znaczeniowego pendant w przekładach funkcjonujących w języku docelowym, albo gdy autor uprawia egzegezę na podstawie własnych przekładów, pokazując możliwość innych, nowych odczytań. W takich sytuacjach tłumacz ma różne możliwości. Jeżeli egzegeza ta jest integralną częścią szerszych wywodów, to musi zwykle negocjować możliwość przekładu dosłownego, nieopartego na autorytecie przekładów opublikowanych i zaaprobowanych. Tak było np. w przypadku przekładu

19 Konstytucja dogmatyczna o Objawieniu Bożym, [online] https://www.swietywojciech.pl/ Strefa-katechety/Bezplatne-pomoce-do-pobrania/Szkola-ponadgimnazjalna/Konstytucja-dogmatyczna-o-Objawieniu-Bozym-DEI-VERBUM, 10 [11.12.2018].

${ }^{20}$ Interpretacja Pisma Świętego w Kościele, Papieska Komisja Biblijna, 10 maja 2005. W artykule nie rozważam różnorodnych problemów szczegółowych, przed jakimi przez stulecia stawali i wciąż stają tłumacze Biblii, bo rozsadziłoby to ramy niniejszego artykułu, którego celem jest odpowiedź na bardziej fundamentalne pytanie o różnice między przekładem świeckim a religijnym. Problemami szczegółowymi zajmują się liczne prace poświęcone przekładom biblijnym, z nowszych np. M. Wojciechowski, Stabe punkty polskiego tlumaczenia Ewangelii w Biblii Tysiaclecia, „Biblica et Patristica Thoruniensia” 9 (2016) 4, s. 151-163; M. Majewski, Jak przekłady zmieniaja Biblię. O teorii i praktyce tłumaczenia Pisma Świętego, Kraków 2013 (skrypt).

${ }^{21}$ Zalecenia Kongregacji Kultu Bożego i Dyscypliny Sakramentów w Instrukcji Liturgiam authenticam są w tej kwestii jednoznaczne: „w żadnym wypadku nie wolno dokonywać przekładów z tłumaczeń opracowanych już na inne języki, [...] należy tłumaczyć bezpośrednio z tekstów oryginalnych" (pkt 24). 
książki Klausa Bergera Po co Jezus umart na krzyżu² czy tekstów Gerharda Lohfinka autorstwa Elizy Pieciul-Karmińskiej ${ }^{23}$. Jeżeli rozbieżność w przekładach dotyczy tylko niewielkiego fragmentu, a nie ma przekładu w języku docelowym, który oddawałby sens w identyczny sposób, to może w przypisie zostać zaznaczone, że przekład jest tłumaczeniem dosłownym z konkretnego języka. W Naśladowaniu [Nachfolge] Dietricha Bonhoeffera w moim przekładzie w odniesieniu do cytatu Błogosławieni dźwigający cierpienie, albowiem oni będa pocieszeni (Mt 5,4 BT), który w przekładzie Tysiąclatki brzmi: Błogostawieni, którzy się smuca, albowiem oni będa pocieszeni, w przypisie pojawia się informacja, że konkretny fragment cytatu, a mianowicie fraza „dźwigający cierpienie" to dosłowne tłumaczenie z niemieckiego przekładu Biblii Lutra, który używa pojęcia Leidtragende ${ }^{24}$.

Ale przekład w kontekście i z uwzględnieniem Tradycji nie jest tylko domeną katolicyzmu. Dotyczy to także pozostałych denominacji chrześcijańskich oraz innych religii. W protestantyzmie istnieje wprawdzie zasada sola scriptura, która w swym pierwotnym rozumieniu czyniła Biblię jedynym autorytetem i odrzucała Tradycję i ustalenia Kościoła. Z perspektywy czasu trzeba jednak powiedzieć po pierwsze, że Tradycja katolicka została zastąpiona protestancką (lub różnymi tradycjami) i często jest ona restrykcyjnie przestrzegana, co szczególnie widać w pewnego rodzaju konserwatyzmie nazewniczym, który thumacz musi uwzględnić, ponieważ język ma tu poniekąd znaczenie tożsamotwórcze (np. używanie słowa zbór). Po drugie, jak zauważa Mieczysław Polak, powołując się na Karla Rahnera:

Potoczne rozumienie pojęcia „tradycja” może prowadzić do różnych nieporozumień. Jednym z nich jest na przykład twierdzenie, że Kościoły protestanckie odrzucają Tradycję, a przyjmują tylko Pismo Święte. „Sola scriptura Reformacji nie jest już jednak doktryną, która dzieli Kościoły" (Karl Rahner) ${ }^{25}$.

Uwzględnienie Tradycji bądź różnych tradycji w przekładzie religijnym ma stąd istotne znaczenie i musi być respektowane przez tłumacza.

${ }^{22}$ K. Berger, Po co Jezus umart na krzyżu? [Wozu ist Jesus am Kreuz gestorben], thum. E. Pieciul-Karmińska, Poznań 2004.

${ }^{23}$ Problematyczny w tym sensie był przekład Magnificat w G. Lohfink, L. Weimer, Maryja nie bez Izraela. Nowe spojrzenie na nauke o Niepokalanym Poczęciu [Maria - nicht ohne Israel. Eine neue Sicht der Lehre von der Unbefleckten Empfängnis], tłum. E. Pieciul-Karmińska, Poznań 2010 czy też przekład Psalmów w G. Lohfink, Modlitwa moją ojczyzną. Teologia i praktyka modlitwy chrześcijańskiej [Gebet schenkt Heimat. Theologie und Praxis des christlichen Gebets], thum. E. Pieciul-Karmińska, Poznań 2011. Informację podaję za autorką przekładu.

${ }^{24}$ Por. D. Bonhoeffer, Naśladowanie, s. 90.

${ }^{25}$ M. Polak, Pismo Święte czy Tradycja? „Przewodnik katolicki” 7/2004, [online] https://opoka.org.pl/biblioteka/T/TD/zkatechizmu_07.html [25.01.2018]. 


\section{Inkulturacja}

Uwzględnienie Tradycji nie oznacza wszakże ślepego powielania. Warto w tym miejscu wrócić jeszcze raz do cytatu z Eliadego, który mówi w pierwszej części, że człowiek religijny sytuuje się w środku świata. Ma to znaczenie również dla przekładu tekstów religijnych, ponieważ ich tłumacz nie abstrahuje od świata. Wynika to już z cytowanego wcześniej dokumentu Interpretacja Pisma Świętego w Kościele, w rozdziale czwartym któregoż, zatytułowanym Interpretacja Biblii w życiu Kościoła, Papieska Komisja Biblijna podejmuje temat inkulturacji, pisząc:

Pierwszy etap inkulturacji polega na przetłumaczeniu natchnionego Pisma św. na inny język. Etap ten jest wzmiankowany już w Starym Testamencie, który wspomina o tym, jak to tekst hebrajski Biblii był ludziom przekazywany naprzód ustnie po aramejsku (Neh 8,8.12), a potem już na piśmie po grecku. Tłumaczenie nigdy bowiem nie jest czymś w rodzaju tylko transkrypcji tekstu oryginalnego. Przejście od jednego języka do drugiego pociąga za sobą z konieczności zmianę kontekstu kulturowego: same pojęcia nie są identyczne, odmienne przesłanie zawiera się w poszczególnych symbolach ponieważ pozostaje ono w nurcie innych tradycji myślowych i w kontekście odmiennych stylów życia.

Nowy Testament, napisany po grecku, w całej swej rozciągłości, nosi na sobie znamiona dynamizmu inkulturacji. Stanowi on bowiem swoistą transpozycję palestyńskiego orędzia Jezusa na kategorie kultury judeohellenistycznej, co oznaczało wyraźną wolę wyjścia poza granice jednego tylko środowiska kulturowego ${ }^{26}$.

Problem inkulturacji, jak pokazuje ów fragment, istniał właściwie od samego początku istnienia chrześcijaństwa, a wcześniej już w judaizmie. Z kwestią inkulturacji mierzyli się też zawsze wielcy tłumacze Pisma św. jak św. Hieronim, Luter czy Nida. Ten ostatni, pracując w Amerykańskim Towarzystwie Biblijnym, sformułował koncepcję ekwiwalencji dynamicznej właśnie na bazie pracy nad przekładami Biblii:

In such a translation the focus of attention is directed, not so much toward the source message, as toward the receptor response. A dynamic-equivalence (or D-E) translation may be described as one concerning which a bilingual person can justifiable say, "That is just the way we would say it" ${ }^{\prime 27}$.

Przekład religijny musi zatem uwzględniać też ten aspekt, odpowiadając sobie na pytanie, jak w danym języku i danej kulturze nazwano by daną rzecz. Nie dotyczy to oczywiście tylko przekładów biblijnych. Ten sam tekst religij-

${ }^{26}$ Interpretacja...

27 E.A. Nida, Toward a Science of Translating: With Special Reference to Principles and Procedures Involved in Bible Translating, Leiden 1964, s. 166: „,[w] takim przekładzie uwaga skoncentrowana jest nie tyle na przekazie źródłowym, ile na reakcji odbiorcy. Tłumaczenie dążące do ekwiwalencji dynamicznej można opisać jako takie, o którym dwujęzyczna osoba może w sposób uzasadniony powiedzieć: «Tak właśnie byśmy to powiedzieli»» (tłum. J.K.). 
ny czy teologiczny może zostać inaczej przełożony w zależności od tego, czy przekład sporządzany jest dla katolików czy dla protestantów, inkulturacja nie jest tutaj zatem związana tylko z przekładem na inny język (np. z przekładem z języka niemieckiego na język polski), ale też na inną kulturę religijną, która wiąże się np. z odmiennymi tradycjami nazewniczymi, Tradycją czy innymi sposobami głoszenia. Jeżeli nie dojdzie do inkulturacji, to może się zdarzyć, że owe metaforyczne drzwi będą dla odbiorcy zamknięte, tzn. obcość kulturowa sprawi, że zamknie się on na przekaz i w ten sposób niemożliwe stanie się „porozumiewanie się” za pośrednictwem tego tekstu z Bogiem. Przykładem takiej inkulturacji jest katolicki przekład Naśladowania i późniejsza redakcja i adaptacja ewangelicka spolszczenia ${ }^{28}$. Jednocześnie jednak przy inkulturacji czyhają na tłumacza pewne niebezpieczeństwa. Wzmiankowany dokument Papieskiej Rady ostrzega przed dwoma: powierzchowną adaptacją oraz synkretyczną kompilacją:

Całkowita wierność osobie Chrystusa, dynamizmowi Jego tajemnicy paschalnej oraz miłość do Kościoła, pozwalają uniknąć dwu rozwiązań błędnych: powierzchownej „adaptacji” orędzia biblijnego oraz jego rozpłynięcia się w synkretycznej kompilacji ${ }^{29}$.

W tym kontekście problematyczne są m.in. napiętnowane przez Zespół Języka Religijnego Rady Języka Polskiego przekłady Pisma Świętego na gwary i regionalne bądź środowiskowe odmiany języka. Autorzy noty krytycznej zauważają:

Tego typu zabiegi „translatorskie” nie służą, naszym zdaniem, udostępnianiu Pisma Świętego, ale narażają jego treść na językową trywializację, a na płaszczyźnie doświadczenia religijnego na bezrefleksyjne mieszanie sacrum z profanum. Nie mają też, niestety, wartości literackiej, która mogłaby być argumentem na ich „obronę”.

Pomysły wątpliwej jakości merytorycznej i nieumiejętne wykonanie szkodzą tekstom uznawanym przez chrześcijan za święte. Szkodzą też dialektowi czy gwarze. Na niewiele zda się również szermowanie hasłem inkulturacji, jeśli przedstawiane teksty będą niedopracowane, a z lokalnej bądź środowiskowej kultury brać będą w sposób nieprzemyślany tylko pewne powierzchowne elementy. Takie zabiegi nie przysłużą się ani ewangelizacji, ani szacunkowi dla regionalizmów i gwar $^{30}$.

28 Por. D. Bonhoeffer, Naśladowanie [Nachfolge], thum. J. Kubaszczyk, Poznań 1997 oraz tenże, Naśladowanie 2017. Protestantyzacja (czyli inkulturyzująca adaptacja) wcześniejszego przekładu katolicyzującego była możliwa dzięki konsultacji i redakcji spolszczenia dokonanej przez teologa ewangelickiego Jerzego Sojkę.

${ }^{29}$ Interpretacja....

30 A. Czesak i in., Uwagi o współczesnych przekładach Biblii, Rada Języka Polskiego, 2007, [online] http://www.rjp.pan.pl/index.php?option=com_content\&view=article\&id=154:uwagi-o-wspolczesnych-przekadach-biblii\&catid $=55 \&$ Itemid $=67$ [14.11.2018]. 


\section{Kultura religijna i wyznawane wartości}

Kwestia inkulturacji wiąże się też ściśle z językiem używanym w przekładanych tekstach religijnych, sposobem formułowania myśli oraz ze sferą wyznawanych wartości. W cytowanym dokumencie mowa jest dalej w kontekście inkulturacji m.in. o sferze odczuć, sposobów myślenia, stylu życia i wyrażania się specyficznego dla danej kultury lokalnej ${ }^{31}$.

Jak wiadomo z badań psychologicznych, lingwistycznych i pragmalingwistycznych, sposób myślenia i wyrażania się jest silnie uwarunkowany kulturowo ${ }^{32} \mathrm{i}$,przekopiowany” może spowodować odrzucenie przesłania. Ten etap inkulturacji związany również z przekładem wiąże się m.in. z aprobowaną w danej kulturze sferą wartości. Nie chodzi tutaj przy tym o wartości czysto religijne, ale z religią skorelowane. Aby to wyjaśnić, można odwołać się na przykład do różnic między kulturą katolicką a protestancką. Brieskorn, charakteryzując religię w kulturze niemieckiej, pisze w odniesieniu do kultury protestanckiej:

Von der Augsburgischen Konfession ausgehend, formte sich eine protestantische Kultur. Keineswegs kämpfte man lediglich innerhalb eines engen theologischen Fachzirkels, das Volk beteiligte sich oft intensiv an den Auseinandersetzungen und bildete sich eine neue, seine Kultur. Nicht alle Kunstzweige wurden zum Leidwesen so mancher weitergepflegt, mancher Ergötzung musste man sich entsagen, und Fröhlichkeit verkrümmte etwas. Das Leben enthielt einen ernsteren und schwereren Charakter zugesprochen ${ }^{33}$.

Brieskorn wskazuje zatem na takie cechy kultury protestanckiej jak powaga, deprecjonowanie radości i zabawy. Można by tu pewnie dorzucić jeszcze nieufność względem uczuć i intelektualizację, której nie należy mylić z racjonalizmem. Opis ten dotyczy co prawda kultury protestanckiej, środkami filmowymi przepięknie ukazanej w filmie Uczta Babette ${ }^{34}$, ale myślę, że można postawić zasadne pytanie, jak dalece silna obecność protestantyzmu przez pół tysiąclecia w takich krajach czy adekwatniej obszarach kulturowych jak np. Niemcy wpłynęła również na protestantyzację katolicyzmu w danym kraju.

31 Tamże.

${ }^{32}$ Por. np. P. Boski, Kulturowe ramy zachowań społecznych. Podręcznik psychologii międzykulturowej, Warszawa 2010.

${ }^{33}$ N. Brieskorn, Die Religion in der deutschen Kultur [w:] Religion und Kirche in der modernen Gesellschaft: polnische und deutsche Erfahrungen. Veröffentlichungen des Deutschen PolenInstituts, hrsg. v. E. Kobylińska, A. Lawaty, Wiesbaden 1994, s. 75-94, tu: s. 83: „[w] oparciu o wyznanie augsburskie powstała kultura protestancka. Bynajmniej nie walczono jedynie w wąskim gronie teologicznych ekspertów, społeczeństwo uczestniczyło często intensywnie w sporach, tworząc nową, swoją kulturę. Ku ubolewaniu wielu nie rozwijano nadal wszystkich gałęzi sztuki, trzeba się było wyrzec wielu przyjemności, a radość nieco skarlała. Życiu nadano poważniejszy i cięższy charakter (tłum. J.K.).

${ }^{34}$ G. Axel (reż.), Uczta Babette [Babettes gæstebud], na podstawie opowiadania Karen Blixen, Dania 1987. 
Polski katolicyzm cechuje natomiast dużo większa emocjonalność, liryczność oraz sprzężenie z pierwiastkiem narodowym, co wiąże się między innymi z odwoływaniem się w tekstach religijnych do historii (bogoojczyźnianość). Pewne koncepcje, budzące pozytywne konotacje ze względu na historię Polski, pojawiające się w polskich tekstach religijnych, mogą być niezrozumiałe dla odbiorcy niemieckiego, np. następujący tekst, odwołujący się w sferze symbolicznej do demokracji szlacheckiej i instrumentu wolnej elekcji:

Tuż przed północą Prymas Polski odebrał od młodzieży symboliczny Akt Elekcji Chrystusa. „Wybrać Chrystusa na króla swojego życia, to podporządkować Jemu własne cele, Jemu oddać własną wolność. Mieć Chrystusa za Króla, to znaczy żyć według Jego praw i zasad, które objawił w Ewangelii” — mówił kard. Józef Glemp ${ }^{35}$.

Odbiorca niemiecki może mieć też trudność z akceptacją emocjonalności w polskim życiu duchowym, w polskiej religijności. Natomiast teksty niemieckie, pozbawione z reguły emocjonalności, mogą się wydawać polskim odbiorcom przeintelektualizowane. Kwestia emocjonalności jest oczywiście sprawą gradacji. W publikacji cytowanej już powyżej, w wywiadzie z ojcem Janem Górą pada pytanie:

Polskie przeżywanie wiary jest dosyć statyczne, powściągliwe, ułożone, bardzo się różni od chrześcijaństwa w Afryce czy nawet w Europie Południowej. Natomiast Lednica to jest żywioł i entuzjazm. Jaki jest na to sposób? Może po prostu łatwiej wykrzesać entuzjazm z młodych ludzi niż z dorosłych i starszych, którzy stanowią większość w naszych parafiach? ${ }^{36}$

Różnice w emocjonalności mogą stanowić niekiedy większą barierę niż różnice językowe, sprawiając, że teksty religijne odebrane będą w przekładzie jako nudne, zimne, drewniane, przeintelektualizowane lub przeciwnie egzaltowane, czułostkowe, zbyt metaforyczne, zbyt mało precyzyjne itp. W jednym z dalszych wywiadów w tejże książce Tomasz Dostatni twierdzi, że młodzież „naprawdę woli język symboli i obrazu od długich wywodów intelektualno-naukowych"37, zatem można założyć, że typowo niemiecka prezentacja prawd wiary mogłaby być w takiej sytuacji chybiona. Nie jest może zatem dziełem przypadku, że Ruch Nowej Ewangelizacji posiłkuje się kaznodzieją z Afryki czy Włochami z Brazylii, a nie na przykład z Niemiec, ze względu na to, że są oni kulturowo Polakom bliżsi przez większą emocjonalność przekazu (abstrahując oczywiście od istotnych kwestii duchowych). Tłumacz ma stosunkowo niewielkie możliwości zniwelowania tych różnic, ale wpływają one na pewno na akceptację przekładu i przekazu treści religijnych w kulturze docelowej.

${ }^{35}$ G. Polak Przeżyjmy to jeszcze raz [w:] Lednica Góra! Elementarz Ojca Jana, red. M. Kwiatkowska, G. Polak, Warszawa-Poznań 2004, s. 72-104, tu: s. 91.

36 Tenże, Rozmowa z Ojcem Janem Góra [w:] Lednica Górą! Elementarz Ojca Jana, red. M. Kwiatkowska, G. Polak, Warszawa-Poznań 2004, s. 54-70, tu: s. 59.

${ }^{37}$ M. Perfuński, Lednica odmienia. Rozmowa z o. Tomaszem Dostatnim [w:] Lednica Górą! Elementarz Ojca Jana, red. M. Kwiatkowska, G. Polak, Warszawa-Poznań 2004, s. 111-115, tu: s. 113. 


\section{Podsumowanie}

W artykule mogły zostać omówione tylko wybrane aspekty różniące przekład religijny od innych rodzajów przekładu, jednak już z nich wyłania się jasny obraz tego, że fenomen przekładu religijnego różni się istotowo od przekładu świeckiego. Na czym polega owa differentia specifica? Czym różni się praca thumacza w sferze profanum i w sferze sacrum? Myślę, że najbardziej fundamentalna różnica dotyczy otwarcia się w przekładzie religijnym tłumacza na działanie Ducha św., postawy służebności wobec Słowa rozumianego jako Boże działanie, tak aby słuchaczom umożliwić porozumiewanie się z Bogiem. Inne elementy omówione w tym artykule, jak odwoływanie się do określonych tradycji czy inkulturacja, mogą pojawić się też w przekładzie świeckim.

Chciałabym zakończyć niniejsze rozważania cytatem z Apokalipsy. Dla tłumacza działającego w sferze sacrum zgodnie z Bożą obietnicą nagrodą mogą być drzwi otwarte, gdy zachowa Boże słowo:

To mówi Święty, Prawdomówny, Ten, co ma klucz Dawida, Ten, co otwiera, a nikt nie zamknie, i Ten, co zamyka, a nikt nie otwiera. Znam twoje czyny. Oto postawiłem jako dar przed tobą drzwi otwarte, których nikt nie może zamknąć, bo ty chociaż moc masz znikomą, zachowałeś moje słowo i nie zaparłeś się mego imienia (Ap 3,7-8).

\section{"Closed Door" or "Open Gate": the Translator between the Sacred and the Profane}

\section{Summary}

The paper reflects on the specificity of the translation of texts belonging to the religious and theological literature. Religious and theological texts have been translated for millennia, many of them originating in the sphere of Judeo-Christianity - lie at the core of Western culture. Their translation, especially the translation of the Bible, was accompanied by theoretical reflection (see, for example, Jerome of Stridonium, Martin Luther or Eugene Nida), which permanently influenced the way of thinking about translation in general. The present study answers the question of how the translation of religious and theological texts differs from the translation of other texts and what the translator must or should take into account, translating religious and theological texts. The paper discusses, among others, the role of the word in Christianity, spiritual preparation, openness to the Holy Spirit, tradition and inculturation.

\section{Keywords}

translation, interpretation, religious texts, religion, tradition, inculturation, religious culture, values

\section{Słowa kluczowe}

przekład, tłumaczenie, teksty religijne, religia, tradycja, inkulturacja, kultura religijna, wartości 


\section{Bibliografia}

Adamiak E., Imię Boga jest nieprzettumaczalne. Spór o przektady Pisma Świętego, „Tygodnik Powszechny", 2 stycznia 2007, [online] https://www.tygodnikpowszechny.pl/imie-boga-jest-nieprzetlumaczalne-138003 [12.11.2018].

Adhortacja apostolska Verbum Domini, [online] https://w2.vatican.va/content/dam/benedict-xvi/pdf/apost_exhortations/documents/hf_ben-xvi_exh_20100930_verbum-domini_pl.pdf [11.12.2018].

Axel G. (reż.), Uczta Babette [Babettes gæstebud], Dania 1987.

Berger K., Po co Jezus umart na krzyżu? [Wozu ist Jesus am Kreuz gestorben], tłum. E. Pieciul-Karmińska, Poznań 2004.

Bibel in gerechter Sprache, hrsg. v. U. Bail, F. Crüsemann, M. Crüsemann, E. Domay, Gütersloh 2006.

Biblia Tysiaclecia, wyd. 3 poprawione, Poznań-Warszawa 1980.

Bonhoeffer D., Naśladowanie [Nachfolge], thum. J. Kubaszczyk, Katowice 2017 [wcześniejsze wydanie polskie: Naśladowanie, thum. J. Kubaszczyk, Poznań 1997].

Boski P., Kulturowe ramy zachowań społecznych. Podręcznik psychologii międzykulturowej, Warszawa 2010.

Brieskorn N., Die Religion in der deutschen Kultur [w:] Religion und Kirche in der modernen Gesellschaft: polnische und deutsche Erfahrungen. Veröffentlichungen des Deutschen Polen-Instituts, hrsg. v. E. Kobylińska, A. Lawaty, Wiesbaden 1994, s. 75-94.

Czesak A., Kąś J., Koziara S., Przybylska R., Przyczyna W., Synowiec H., Włodyga P., Wróbel R, Uwagi o współczesnych przekładach Biblii, Rada Języka Polskiego, 2007, [online] http:// www.rjp.pan.pl/index.php?option=com_content\&view $=$ article \&id=154:uwagi-o-wspoczesnych-przekadach-biblii\&catid=55\&Itemid=67 [14.11.2018].

Eliade M., Sacrum, mit, historia, Warszawa 1993.

Gomola A., Myśl feministyczna w przekładach Biblii, „Przekładaniec” 24 (2011), s. 212-227.

Gutzen D., „Denn wer dolmetzschen wil, mus grosse vorrath von worten haben.” Von Luthers Bibelübersetzung zur Bibel in gerechter Sprache [w:] Gutes Übersetzen: Neue Perspektiven für Theorie und Praxis des Literaturübersetzens, hrsg. v. A. Buschmann Berlin-Boston 2015, s. 243-281.

Instrukcja Liturgiam authenticam, Kongregacja Kultu Bożego i Dyscypliny Sakramentów, 28 marca 2001, [online] https://opoka.org.pl/biblioteka/W/WR/kongregacje/kkultu/instrukcja_liturgiam_28032001.html [14.11.2018].

Interpretacja Pisma Świętego w Kościele, Papieska Komisja Biblijna, 10 maja 2005, [online] http://biblia.wiara.pl/doc/423152.INTERPRETACJA-PISMA-SWIETEGO-W-KOSCIELE [25.01.2018].

Kodeks Prawa Kanonicznego, 1983, [online] http://www.trybunal.mkw.pl/Kodeks\%20Prawa\%20 Kanonicznego.pdf [12.11.2018].

Konstytucja dogmatyczna o Objawieniu Bożym Dei Verbum [online] https://www.swietywojciech. pl/Strefa-katechety/Bezplatne-pomoce-do-pobrania/Szkola-ponadgimnazjalna/Konstytucja-dogmatyczna-o-Objawieniu-Bozym-DEI-VERBUM, 10, [11.12.2018].

Lohfink G., Modlitwa moja ojczyzną. Teologia i praktyka modlitwy chrześcijańskiej [Gebet schenkt Heimat. Theologie und Praxis des christlichen Gebets], tłum. E. Pieciul-Karmińska, Poznań 2011. 
Lohfink G., Weimer L., Maryja - nie bez Izraela. Nowe spojrzenie na naukę o Niepokalanym Росzе̨сiи [Maria - nicht ohne Israel. Eine neue Sicht der Lehre von der Unbefleckten Empfängnis], tłum. E. Pieciul-Karmińska, Poznań 2010.

Majewski M., Jak przekłady zmieniaja Biblię. O teorii i praktyce tlumaczenia Pisma Świętego, Kraków 2013 [skrypt], [online] https://upjp2.academia.edu/MarcinMajewski [12.11.2018].

Nida E.A., Toward a Science of Translating: With Special Reference to Principles and Procedures Involved in Bible Translating, Leiden 1964.

Perfuński M., Lednica odmienia. Rozmowa z o. Tomaszem Dostatnim [w:] Lednica Górą! Elementarz Ojca Jana, red. M. Kwiatkowska, G. Polak, Warszawa-Poznań 2004, s. 111-115.

Polak G., Przeżyjmy to jeszcze raz [w:] Lednica Górą! Elementarz Ojca Jana, red. M. Kwiatkowska, G. Polak, Warszawa-Poznań 2004, s. 72-104.

Polak G., Rozmowa z Ojcem Janem Górą [w:] Lednica Górą! Elementarz Ojca Jana, red. M. Kwiatkowska, G. Polak, Warszawa-Poznań 2004, s. 54-70.

Polak M., Pismo Święte czy Tradycja?, „Przewodnik katolicki” 7 (2004), [online] https://opoka.org. $\mathrm{pl} /$ biblioteka/T/TD/zkatechizmu_07.html [25.01.2018].

Reiss K., Vermeer H.J., Towards a General Theory of Translational Action: Skopos Theory Explained, Manchester 2013.

Smend R., Wohltuendes Durcheinander. Biblische Predigten, Stuttgart 2007.

Wojciechowski M., Stabe punkty polskiego tlumaczenia Ewangelii w Biblii Tysiaclecia, „Biblica et Patristica Thoruniensia" 9 (2016) 4, s. 151-163. 